\title{
Communication
}

[Comunicação]

\section{Serum levels of soluble interleukin-2 receptor (sIL-2R) and cancer antigen 125 (CA 125) in dogs diagnosed with cutaneous lymphoma}

[Níveis séricos do receptor solúvel de interleucina-2 (sIL-2R) e antígeno do câncer 125 (CA 125) em cães diagnosticados com linfoma cutâneo]

\author{
I.C. Canavari ${ }^{1}$, I.L.S. Senhorello ${ }^{3}$, C. Goloni ${ }^{1}$, F.A.R. Sueiro ${ }^{4}$, M. Tinucci-Costa ${ }^{2}$ \\ ${ }^{1}$ Aluna de pós-graduação - Faculdade de Ciências Agrárias e Veterinárias - Universidade Estadual \\ Paulista - Jaboticabal, SP \\ ${ }^{2}$ Faculdade de Ciências Agrárias e Veterinárias - Universidade Estadual Paulista - Jaboticabal, SP \\ ${ }^{3}$ Universidade Vila Velha - Vila Velha, ES \\ ${ }^{4}$ Autonômo - Campinas, SP
}

Lymphoma is one of the most common neoplasms diagnosed in dogs. Its incidence varies according to its anatomical classification, with the cutaneous form representing $<1 \%$ of all canine cutaneous tumors (Chan et al., 2018; Vail et al., 2019). Cutaneous lymphoma incidence appears to be higher in Brazil, although epidemiological studies are lacking (Duarte et al., 2016). Cutaneous lymphomas can develop with a poor prognosis due to disease aggressiveness, rapid clinical progression and reduced survival in both epitheliotropic and non-epitheliotropic forms (Moore et al., 2013; Chan et al., 2018).

The soluble interleukin-2 receptor (sIL-2R) is found in immune cells such as lymphocytes, macrophages, and monocytes. Soluble IL-2 receptor is released into body fluids following the neoplastic activation of lymphocytes (Bien and Balcerska, 2008). Studies have correlated elevated serum concentrations of sIL-2R with increased tumor aggressiveness and lower survival rates in human patients diagnosed with a cutaneous lymphoma (Vonderheind et al., 1998).

Glycoprotein cancer antigen 125 (CA 125) was initially identified in ovarian carcinomas in women; however, increased concentrations of CA 125 in human non-Hodgkin's lymphoma cases have been associated with disease progression, degree of tumor aggressiveness and occurrence of effusions (Lazzarino et al., 1998). This study evaluated whether the serum concentrations of
sIL-2R and CA 125 could be used as additional non-invasive tools for tumor staging and to establish the prognosis in dogs diagnosed with cutaneous lymphoma. The present study was approved by the Ethics Committee on the Use of Animals (CEUA) of the School of Agricultural and Veterinary Sciences of the São Paulo State University (UNESP) in Jaboticabal, SP (protocol 9.252/16).

The diagnosis of cutaneous lymphoma in 15 dogs was made by cytological and histopathological examinations; therefore, epitheliotropic and nonepitheliotropic forms were included in the study. Tumor staging in all animals was achieved by physical examination, chest radiographs, and abdominal ultrasound, in addition to blood count and serum biochemistry. Blood serum from healthy animals $(n=10)$ with no history of neoplasms or other comorbidities that had undergone pre-vaccination screening was used as a control for the serological evaluations. After the diagnosis was confirmed, treatment was based on chemotherapy with lomustine (70 to $90 \mathrm{mg} / \mathrm{m}^{2}$ ) every 21 days associated with prednisone (Vail $e t$ al., 2019). However, before initiating the therapeutic protocol, $4 \mathrm{~mL}$ of blood was collected from each dog, followed by centrifugation. Serum was removed, individually aliquoted and stored at $-80^{\circ} \mathrm{C}$ for the subsequent measurement of serological markers. 
For the quantitative determination of sIL-2R levels, $200 \mu \mathrm{L}$ of blood serum that was individually aliquoted from the control and cutaneous lymphoma groups was assayed using an IL-2R canine ELISA kit (MyBiosource, CA, USA), and the reading was performed using a Stat Fax 2100 microplate reader (Awareness Technology). Similarly, for the CA 125 assays, $300 \mu \mathrm{L}$ of blood serum from each of the groups was assayed using a human ELISA kit (AccuBind ELISA Kits - MONOBIND INC, USA), and the reading equipment used was Elisys Uno Human ${ }^{\circledR}$ following the manufacturer's instructions.

The statistical analyses followed a $2 \times 2$ factorial scheme ( 2 groups and 2 methods) in a randomized design, with the number of repetitions ranging from $n=10$ to $n=15$. For the analysis of variance, the data were log-transformed (observation +1 ) and compared by Tukey's test at a 5\% significance level. The General Linear Models (GLM) procedure of SAS software was used for the analyses (SAS 9.1, SAS Institute, Cary, NC, USA). The serum concentrations of sIL-2R and CA 125 were measured in the control and cutaneous lymphoma groups. The cutaneous lymphoma group comprised 6 and 9 animals diagnosed with the epitheliotropic and nonepitheliotropic forms, respectively. The mean age of the control group and the group of animals with cutaneous lymphoma was 4.8 and 8.6 years, respectively. Mixed breeds were the most prevalent in this study (Table 1)

The survival time of the animals in this study was counted from the time of the histopathological diagnosis until death. The average survival time of dogs with cutaneous lymphoma was 27 days. The low average survival of patients with cutaneous lymphoma and the higher incidence of the non-epitheliotropic form corroborate the study by Duarte et al. (2016). Notably, 6 of the 15 animals in this group (40\%) died before the conclusive diagnosis of cutaneous lymphoma due to disease progression, 5 animals were not submitted to chemotherapy because of their clinical conditions and/or the tutor's resolution, and 4 animals began chemotherapy. Only one animal completed the chemotherapy protocol; however, the lymphoma relapsed later, and the patient died due to complications of the neoplasm. The other animals died during the chemotherapy protocol. The reduced survival of dogs with cutaneous lymphoma highlights the high aggressiveness of both histological types. Table 2 shows the serum concentrations of the sIL-2R and CA 125 markers at the time of diagnosis, without the influence of chemotherapy on the results. There was no difference in the concentrations of sIL-2R and CA 125 between the control and cutaneous lymphoma groups $(\mathrm{P}>0.05)$.

Table 1. Characteristics of the cutaneous lymphoma group $(\mathrm{n}=15)$

\begin{tabular}{lc}
\multicolumn{1}{c}{ Histopathological classification } & $\mathrm{N}$ \\
\hline Epitheliotropic & 6 \\
Non-epitheliotropic & 9 \\
Sex & \\
Female & 10 \\
Male & 5 \\
Breed & \\
Mixed breed & 9 \\
Rottweiler & 1 \\
Golden Retriever & 1 \\
Brazilian Mastiff & 2 \\
Poodle & 1 \\
Boxer & 1 \\
\hline
\end{tabular}

Table 2. Mean \pm SD of serum concentrations of the markers in both groups

\begin{tabular}{lcc}
\hline Groups & sIL 2R $(\mathrm{pg} / \mathrm{ml})$ & CA 125 $(\mathrm{U} / \mathrm{ml})$ \\
\hline Control & $910.029 \pm 371.625$ & $13.400 \pm 18.830$ \\
Cutaneous lymphoma & $625.692 \pm 294.76$ & $12.806 \pm 16.354$ \\
\hline
\end{tabular}

This is the first study evaluating the serum concentrations of sIL-2R in dogs with cutaneous lymphoma using the commercial canine sIL-2R kit. In humans, a positive correlation exists between high concentrations of sIL-2R and the aggressiveness of different non-Hodgkin's lymphomas, including the cutaneous form (Bien and Balcerska, 2008). However, the same association was not identified between the control and cutaneous lymphoma groups in this study under the conditions in which the kit was used.

Mizutani et al. (2020) developed a specific ELISA test to measure serum sIL-2R concentrations in 
dogs diagnosed with different types of lymphoma, and the concentration of sIL-2R was found to be significantly higher in dogs with multicentric high-grade B-cell lymphoma. The same correlation was not found in animals with cutaneous lymphoma; nevertheless, the number of animals in the study was small $(\mathrm{n}=4)$, and sIL$2 \mathrm{R}$ was detected in only one dog. A study using a standard ELISA for use in humans observed higher serum concentrations of sIL-2R in animals with non-neoplastic diseases and benign neoplasms than in animals with malignant neoplasms, including lymphoma cases. Additionally, the authors found a positive correlation between higher sIL-2R concentrations and increased total leukocyte count, suggesting that sIL-2R could be used as an inflammatory marker in dogs, rather than a marker for malignant neoplasms as was expected (Prachar et al., 2013).

In our study, $46.67 \%$ (7/15) of the animals showed normal white blood cell counts $(6.8-14.6 \times$ $\left.10^{3} / \mathrm{uL}\right), 33.33 \%(5 / 15)$ had leukopenia $(3.1-5.3 \times$ $10^{3} / \mathrm{uL}$ ), and only $20 \%$ (3/15) of the dogs with cutaneous lymphoma presented with leukocytosis $\left(22.3-30 \times 10^{3} / \mathrm{uL}\right)$. Considering that sIL-2R can be an inflammatory marker, the total leukocyte count may have contributed to the deregulation of cytokine production and the non-increase of sIL$2 \mathrm{R}$ concentrations in animals with lymphoma in the present study.

The IL-2 receptor comprises three chains $(\alpha, \beta$, and $\gamma$ ), although only the $\alpha$ subunit, encoded by CD25, can be detected as a soluble portion (sIL2R). The association between serum concentrations of sIL-2R and CD25 expression in human cases of diffuse large B-cell lymphoma was studied, and some patients exhibited high serum concentrations of sIL-2R and severe clinical disease, although the expression of CD25 was only detected in a few lymphomatous cells. However, some patients with low serum concentrations of sIL-2R were also in an advanced clinical stage of the disease and showed high expression of CD25 in lymphomatous cells (Yoshida et al., 2013). In dogs with high-grade Bcell lymphoma, no correlation was found between serum concentrations of sIL-2R and CD25 expression in neoplastic cells (Mizutani et al., 2020).

In addition, no correlation was found between serum sIL-2R and CD25 expression in lymphoid cells of skin lesions in human cases of cutaneous T-cell lymphoma (Wasik et al., 1996). Yoshida et al. (2013) related serum concentrations of sIL-2R to matrix-metalloproteinase-9 (MMP-9) production by intratumoral macrophages through MMP-9 cleavage of the IL-2R $\alpha$ chain. Thus, sIL$2 \mathrm{R}$ reflects the composition of the tumor microenvironment and not the tumor burden. With regard to what Yoshida et al. (2013) reported, the cells of the cutaneous lymphoma microenvironment in dogs could not present a high expression of sIL-2R; however, this aspect was not part of the scope of the current research and should motivate complementary studies in the future.

This was the first study conducted among dogs with the objective of associating serum concentrations of CA 125 with the prognosis of cutaneous lymphoma. However, the results did not show significant differences in CA 125 concentrations between the healthy and cutaneous lymphoma groups. In humans, CA 125 is also a prognostic marker studied in aggressive nonHodgkin lymphomas. Interestingly, some results indicate that there is no association between CA 125 and the prognosis of diffuse large B-cell lymphoma, mantle cell lymphoma, anaplastic large cell lymphoma, peripheral T-cell lymphoma, and Burkitt's lymphoma (Bonnet et al., 2007).

It is possible that CA 125 is a glycoprotein of epithelial cell origin. Although a cutaneous lymphoma has cutaneous, mucous, and/or mucocutaneous clinical manifestations, it is a non-Hodgkin lymphoma characterized by the clonal proliferation of atypical lymphocytes in the skin (Vail et al., 2019). Cutaneous lymphoma does not have an epithelial origin, a fact that may have contributed to the non-significant result of the CA 125 dosage.

Studies have shown that CA 125 is not secreted by neoplastic lymphocytes, and its increase in serum would represent an inflammatory stimulus of pleural, pericardial, and peritoneal mesothelial cells, resulting in effusions. Thus, the serum concentration of CA 125 would better reflect the patient's inflammatory response to the disease than the tumor mass (Bonnet et al., 2007). In the present study, only one animal had pleural effusion. Therefore, the fact that most of the dogs in the cutaneous lymphoma group did not present 
an effusive clinical condition may have contributed to the non-significant increase in the serum concentration of CA 125.

The results of this study did not show a clinical significance in the concentrations of the serologic markers sIL-2R and CA 125 in dogs with cutaneous lymphoma for use as auxiliary and noninvasive methods for tumor staging and to relate to the prognosis. However, more large-scale studies evaluating animals throughout the period of treatment that involve the tumor microenvironment are needed to better characterize the influence of sIL-2R and CA 125 on the cancerous behavior of cutaneous lymphoma in dogs.

Keywords: dogs, lymphoma, serological markers, oncology, prognosis

\section{RESUMO}

Marcadores sorológicos são rotineiramente utilizados na prática clínica para o estadiamento de linfomas e para a determinação de seu prognóstico em humanos. No entanto, pouco se sabe sobre sua utilização em cães, mesmo os linfomas sendo neoplasias com alta prevalência nessa espécie. No presente estudo, as concentrações séricas do receptor solúvel de interleucina-2 (sIL-2R) e do antígeno do câncer 125 (CA 125) foram mensurados em 10 cães saudáveis e em 15 cães com linfoma cutâneo, utilizando-se o kit ELISA canino e a leitura em um Stat Fax modelo 2100 (sIL-2R), bem como o kit ELISA humano e a leitura pelo ELISYS UNO humano (CA 125). Os resultados mostraram que não houve diferença significativa $(P<0,05)$ nas concentrações dos marcadores entre os grupos. Além disso, os resultados não apontaram significância clínica no estadiamento tumoral e estabelecimento do prognóstico em cães diagnosticados com linfoma cutâneo.

Palavras-chave: cães, linfoma, marcadores sorológicos, oncologia, prognóstico

\section{ACKNOWLEDGEMENTS}

The authors thank the LEAC Laboratory, São Paulo, and Rodrigo Storti Pereira (CIAPAV, in São José do Rio Preto-São Paulo) for assisting in the part of the study related to the serological markers. This work was financially supported by the Fundação de Amparo a Pesquisa do Estado de São Paulo (FAPESP- process 2016/00128-5) and Coordenação de Aperfeiçoamento de Pessoal de Nível Superior (CAPES).

\section{REFERENCES}

BIEN, E.; BALCERSKA, A. Serum soluble interleukin 2 receptor $\alpha$ in human cancer of adults and children: a review. Biomarkers, v.13, p.1-26, 2008.

BONNET, C.; BEGUIN, Y.; FASSOTTE, M. Limited usefulness of CA125 measurement in the management of Hodgkin's and non-Hodgkin's lymphoma. Eur. J. Haematol., v.78, p.399-404, 2007.
CHAN, C.M.; FRIMBERGER, A.E.; MOORE, A.S. Clinical outcome and prognosis of dogs with histopathological features consistent with epitheliotropic lymphoma: a retrospective study of 148 cases (2003-2015). Vet. Dermatol., v.29, p.154-e59, 2018. cutaneous T-cell lymphoma: a diagnostic conundrum. Vet. Dermatol., v.24, p.204-e45, 2013.

DUARTE, A.; MARQUES, J.; SOARES ZAHN, F. et al. Clinical and laboratorial evaluation of dogs with cutaneous lymphoma treated with lomustine. Braz. J. Vet. Res. Anim. Sci., v.53, p.39-47, 2016.

LAZZARINO, M.; ORLANDL, O.; KLERSY, C. et al. Serum CA 125 Is of clinical value in the staging and Follow-Up of Patients with NonHodgkin's Lymphoma: correlation with tumor parameters and disease activity. Cancer, v.82, p.576-582, 1998.

MIZUTANI, N.; GOTO-KOSHINO, Y.; KURATA, K. et al. Measurement of the concentration of serum soluble interleukin-2 receptor alpha chain in dogs with lymphoma. Vet. Immunol. Immunopathol., v.225, p.1-9, 2020. 
MOORE, P.; AFFOLTER, V.; KELLER, S. Canine inflamed nonepitheliotropic cutaneous $\mathrm{T}$ cell lymphoma: a diagnostic conundrum. Vet. Dermatol., v. 24, p. 204-e45, 2013.

PRACHAR, C.; KAUP, F.J.; NEUMANN, S. Soluble interleukin 2 Receptor-Alpha (sIL-2R $\alpha$ ) in the peripheral blood of dogs-comparison of malignant neoplasia with other diseases. Open. J. Vet. Med., v.3, p.176-183, 2013.

VAIL, D.M.; PINKERTON, M.; YOUNG, K.M. Hematopoietic tumors. In: VAIL, D.M.; THAMM, D.H.; LIPTAK, J.M. (Eds.). Withrow and MacEwen's small animal clinical oncology. 6.ed. Philadelphia: W.B. Saunders. 2019. p.688771.
VONDERHEIND, E.C.; ZHANG, Q.; LESSIN, S.R. et al. Use of serum soluble interleukin-2 receptor levels to monitor the progression of cutaneous T-cell lymphoma. J. Am. Acad. Dermatol., v.38, p.207-220, 1998.

WASIK, M.A.; VONDERHEID, E.C.; BIGLER, R.D. et al. Increased serum concentration of the soluble interleukin-2 receptor in cutaneous T-cell lymphoma: clinical and prognostic implications. Arch. Dermatol., v.132, p.42-47, 1996.

YOSHIDA, N.; ODA, M.; KURODA, Y. Clinical significance of sIL-2R Levels in B-Cell Lymphomas. Plos One, v.8, p.1-10, 2013. 